\title{
Electro-Fermentation in Aid of Bioenergy and Biopolymers
}

\author{
Prasun Kumar ${ }^{1}$, Kuppam Chandrasekhar ${ }^{2}$, Archana Kumari ${ }^{3}$, Ezhaveni Sathiyamoorthi ${ }^{1}$ \\ and Beom Soo Kim ${ }^{1, *}$ \\ 1 Department of Chemical Engineering, Chungbuk National University, Cheongju, Chungbuk 28644, Korea; \\ prasun@cbnu.ac.kr (P.K.); ezhaveni86@gmail.com (E.S.) \\ 2 Department of Civil Engineering, Yeungnam University, Gyeongsan, Gyeongbuk 38451, Korea; \\ chanduibt@gmail.com \\ 3 Department of Biotechnology, Bodoland University, Kokrajhar, Assam 783370, India; \\ archana.bioinfo87@gmail.com \\ * Correspondence: bskim@chungbuk.ac.kr; Tel.: +82-43-2612372; Fax: +82-43-2692370
}

Received: 1 December 2017; Accepted: 30 January 2018; Published: 2 February 2018

\begin{abstract}
The soaring levels of industrialization and rapid progress towards urbanization across the world have elevated the demand for energy besides generating a massive amount of waste. The latter is responsible for poisoning the ecosystem in an exponential manner, owing to the hazardous and toxic chemicals released by them. In the past few decades, there has been a paradigm shift from "waste to wealth", keeping the value of high organic content available in the wastes of biological origin. The most practiced processes are that of anaerobic digestion, leading to the production of methane. However; such bioconversion has limited net energy yields. Industrial fermentation targeting value-added bioproducts such as $-\mathrm{H}_{2}$, butanediols; polyhydroxyalkanoates, citric acid, vitamins, enzymes, etc. from biowastes/lignocellulosic substrates have been planned to flourish in a multi-step process or as a "Biorefinery". Electro-fermentation (EF) is one such technology that has attracted much interest due to its ability to boost the microbial metabolism through extracellular electron transfer during fermentation. It has been studied on various acetogens and methanogens, where the enhancement in the biogas yield reached up to 2-fold. EF holds the potential to be used with complex organic materials, leading to the biosynthesis of value-added products at an industrial scale.
\end{abstract}

Keywords: electro-fermentation; hydrogen; electricity; methane; microbial fuel cells; polyhydroxyalkanoates

\section{Introduction}

Due to rapid industrialization and rising population, the energy crisis and pollution have become the foremost problems that humankind will be facing in the future $[1,2]$. The greenhouse effect in the atmosphere is increasing day by day due to the rapid usage of fossil fuels that discharge $\mathrm{CO}_{2}$, the major greenhouse gas that damages the environment [3]. The hastily intensifying global demand for the limited fossil fuel reserves and the need to control greenhouse gas effects due to $\mathrm{CO}_{2}$ emission into the atmosphere resulting from their usage are driving the research for sustainable carbon-free energy carriers $[4,5]$. In this scenario, many research efforts are currently being dedicated to the search, development, and optimization of eco-friendly and sustainable energy resources to replace fossil fuels. In parallel, novel fermentation technologies, such as the electro-fermentation (EF), is being developed to augment and enhance the potential of conventional fermentation methods [6]. EF is a unique process that deals with the electrochemical control over microbial metabolism. In other words, it is a type of reactor where the biological and electrochemical process occurs at the same time to produce electricity and other bioproducts. The electrodes used during the process can work as 
either electron sources or sinks. Such system allows unbalanced fermentation that has the potential to change the redox balance in the medium. The latter effect can have a significant impact on microbial metabolism and the selection of dominating population within a mixed culture. Originally, most of the EF research work revolved around the generation of electricity and was known as microbial fuel cells (MFCs). Later in time, the research efforts led to the extension of such strategies to produce $\mathrm{H}_{2}, \mathrm{CH}_{4}, \mathrm{CO}_{2}$, polyhydroxyalkanoates (PHA), 1,3-butanediol, etc. In the past decade, EF-based strategies have advanced in various fields such that the compactness and efficiency of the whole setup could become cost-effective and sustainable. It has the potential to expand its application in various research areas of materials science, engineering, waste management, and applied microbiology through an integrative approach. MFCs and microbial electrolysis cells (MECs) based systems were tested on a large scale during the last decade and the results were quite promising [7]. Various companies have demonstrated the large-scale operation of microbial electrochemical technologies (METs) for $\mathrm{CH}_{4}$ [8], for electricity [9,10], on-site conversion of urine into ammonia and $\mathrm{H}_{2}$, and for cost-effective wastewater treatment [11]. Besides these, the METs have potential applications in the area of energy efficient desalination, bioremediation, and biosensors.

For a successful market determination of the bioconversion process, techno-economic analysis is highly desirable. The economic viability of $\mathrm{EF}$ technology has been done as a case-study (anaerobic digestion versus $\mathrm{H}_{2}$ production by MEC; and $\mathrm{H}_{2}$ from MEC versus acetate from the MES process) [9]. Recently, an economic assessment of MFC was done in a juice processing plant [12]. Further sensitivity analysis revealed that electrode area is inversely related to MFC profitability while it is obvious that rise in electricity and / or crude oil price will positively influence the MFC profitability, making MFC a very attractive option. Research and development (R\&D) startups such as Cambrian Innovation [8], Fluencecorp [11], or Electrochaea [13] have translated the concepts of bioelectrochemical system (BES) into large-scale production and applications. Despite heavy investments in pilot-scale operations, only Cambrian Innovations came up with a commercial product (the EcoVolt, Cambrian Innovation Inc., Boston, MA, USA) that can produce 20-300 $\mathrm{kW}$ of power and is expected to be used by the brewery or paper industries. Similarly, initial MFC based applications may primarily focus on wastewater with digestible organics and stable composition (e.g., food and brewery or paper industry). Various pilot level experimental setups have been carried out with these substrates that provided useful insights regarding BES configuration and operation [14,15]. Initial operations based on MFCs may not seem economical (based on the electricity production) and therefore will lead to a longer payback period, but multiple beneficial treatment effects (energy savings, reduction in excess sludge quantity, electricity with value-added co-products and tax/carbon credits) will help in capturing the market.

Renewable electricity (wind and solar) faces challenges of productivity fluctuations, power transport, and storage, thus it needs to be converted to storable chemicals and/or fuels. A US-based start-up "Electrochaea" in association with energy company E.on (E.on SE management, Düsseldorf, Germany) and the Danish government has been working on a two-step conversion system of wind electricity and $\mathrm{CO}_{2}$ into $\mathrm{CH}_{4}$. A direct bioelectrochemical conversion of $\mathrm{CO}_{2}$ to $\mathrm{CH}_{4}$ should be the next step. However, researchers are actively engaged worldwide to overcome the hurdles that must be crossed by this technology to come into actual use/demand by users. Similar to conventional fermentation, EF based processes will also require energy-intensive and costly recovery and purification of valuable compounds. Besides the commonly used procedure of distillation, few selective downstream stages that may be exploited for MES products involves in situ product recovery (crystallization, electrodialysis, membrane filtration), and electrochemically induced co-crystallization.

\section{Waste Biomass: Veiled Opportunity}

The growing urbanization is posing a serious impact on natural resources and environment. The dependency on fossil fuel based energy sources leads to the global problem of pollution and climate change [16,17]. The quest to find alternative resources for petroleum-based products (especially for transportation) has been the major impetus to produce bioenergy from renewable resources [18]. 
In this context, use of waste biomass in a biorefinery could be a potential alternative. Waste generated from agriculture, non-edible or other food wastes, effluents of biochemical industries, etc. are potential sources of raw materials [6]. A large quantity of food wastes is generated annually from food supply chain to agriculture and industrial processing systems. The quantum of such wastes is expected to grow rapidly in the coming 25 years $[19,20]$. Managing such huge quantities of wastes has become a global problem [21,22]. Since they mostly consist of cellulose, lignin, lipids, and proteins, it is imperative to exploit them for producing value-added products.

It thereby gives endless opportunities and offers a win-win situation by the fact that these wastes, including municipal solid wastes go to landfills, leading to groundwater pollution, greenhouse gas emission, and other harmful effects in the vicinity [21,23]. Uses of waste biomass have been shown to produce $\mathrm{H}_{2}, \mathrm{CH}_{4}$, volatile fatty acids (VFA), PHAs, ethanol, and many other bioproducts. Various stochastic models having tremendous industrial potential have been proposed that can be utilized in tandem on a large scale [24]. MFC based systems have also been exploited to treat food and agriculture wastes and extract valuable chemicals along with electricity generation [6]. Fermented canteen wastes have been found to generate $530 \mathrm{~mA} / \mathrm{m}^{3}$ of power density with a concomitant reduction in chemical oxygen demand (COD) of up to $44 \%$ [25]. The rising attention in this area of research has opened intriguing possibilities for the mankind. Figure 1 shows the number of papers published between 1991 and 2017 for the keywords 'bioelectrochemical system', 'microbial fuel cell', and 'microbial electrolysis cell' according to the Scopus database [26]. This indicates that the research interest in the EF-based systems for the generation of other value-added products has increased sharply in the past few years. An enhancement of $>2.5$-folds in the published works were recorded in 2011-2015 as compared to 2006-2010. Such trend continued up to now, as we observed that about one-third of the total number of articles published during 2011-2015 was consecutively published each year (i.e., in 2016 and 2017).

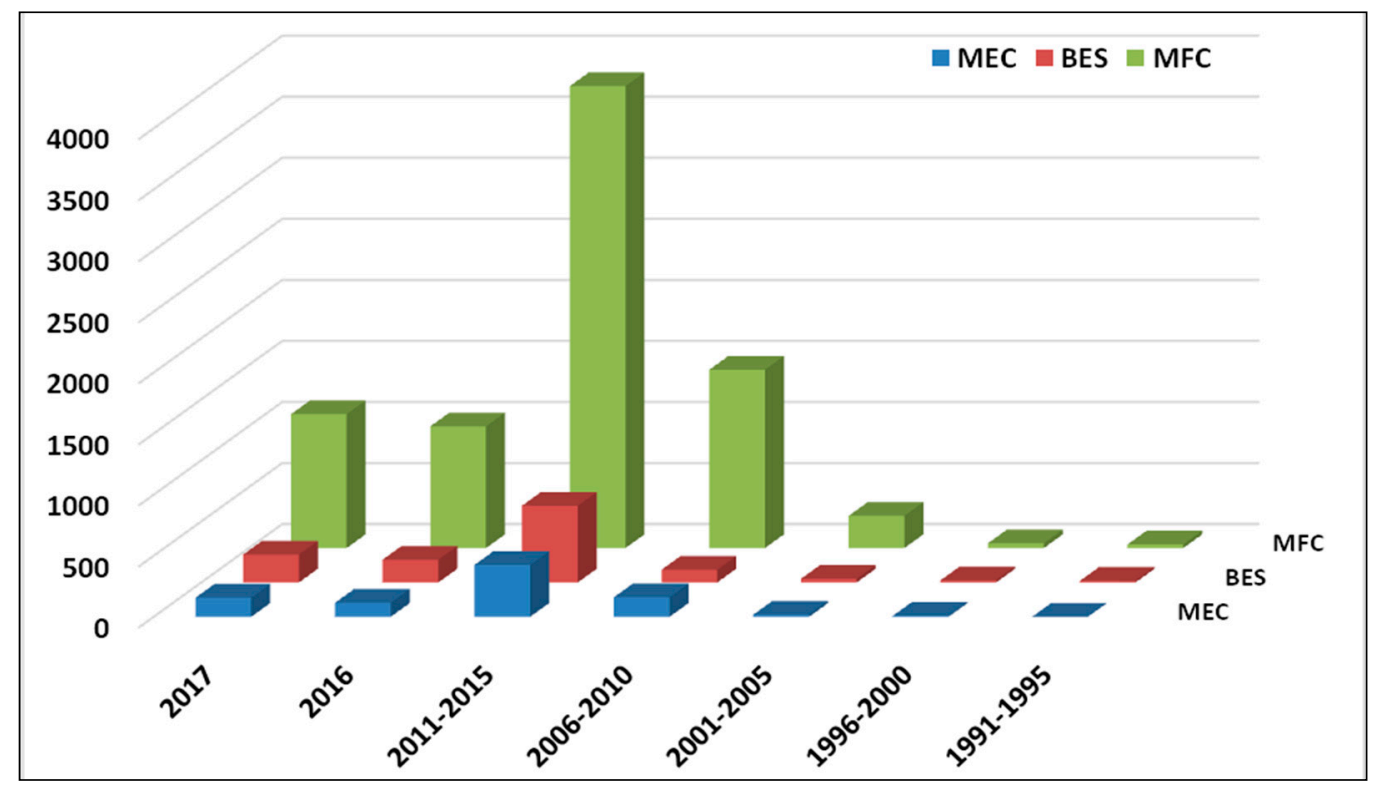

Figure 1. Number of research articles published on different variants of bio-electrochemical system since 1991 to 2017 (Scopus data, accessed on 12 January 2018). MEC: microbial electrolysis cell, BES: bioelectrochemical system, MFC: microbial fuel cell.

\subsection{Anaerobic Digestion and Its Limitations}

Anaerobic digestion is considered as a well-established technology for biogas/biomethane (bio- $\left.\mathrm{CH}_{4}\right)$ production. The final product of anaerobic digestion consists of bio- $\mathrm{CH}_{4}(60 \%$ to $80 \%)$ and $\mathrm{CO}_{2}(20 \%$ to $40 \%)$, whose comparative quantities chiefly depend on the type of substrate used. The anaerobic digestion is a multistep biological process (hydrolysis, acidogenesis, acetogenesis, 
and methanogenesis) mediated by a specific group of microbes, which works together under a strict anaerobic environment [27]. The optimum temperature for the anaerobic digestion process varies between 35 and $55{ }^{\circ} \mathrm{C}$. However, the balance between energy input and total biogas yield is a key factor to determine the choice of anaerobic digester operating temperature. Its successful operation is depended on the acclimatization of mixed cultures, $\mathrm{pH}$ fluctuations, organic loads, retention time, etc. Controlling so many parameters including the variations in the substrate composition makes the process vulnerable for continuous operations and therefore requires consistent observation.

\subsection{Microbial Electro-Fermentation: An Alternative Method of Fermentation}

Electrofermentation is the effective electron capturing process using specialized electrodes during microbial fermentation. It utilizes a low-cost platform with self-sustaining anodifilic microbes to oxidize organic and inorganic acids usually present in waste materials [6]. At its core, a cascade of redox reaction occurs to convert chemical energy into electricity or other products, wherein specific membranes separate the cathode and anode chambers [28-30]. It is the common principle for almost all the EF based reactors. Its dimension and application get a wider reach by the fact that reduction based reaction can take place in the cathode chamber. In the anode compartment, electrochemically active bacteria utilize organic matter and generate electrons and protons. These protons transferred via proton exchange membrane and reach the cathode. Meanwhile, electrons were captured by the anode electrode and transferred them via an electrical circuit to the cathode. In the cathode compartment, electrons and protons are reduced with oxygen molecule, which acts as a terminal electron acceptor. Depending upon the number of compartments and operation type, EF can be categorized into single chambered, double-chambered, tubular, stacked, baffled, up-flow system, etc. [24,31-37]. On the other hand, with different modifications, EFs can further be categorized into bioelectrochemical treatment system (BET), microbial desalination system (MDS), microbial electrolysis cell (MEC), and bioelectrochemical system (BES) extending its utility [24,38-41]. During EF, specialized microbes are exploited based on their electrochemical activities and can be grouped into electrochemically active bacteria, exoelectrogen, electricigen, or anode-respiring bacteria. This implies that microbes are able to transfer electrons outside the cell membranes in a different manner. Microbes belonging to the exoelectrogen category are able to produce electricity at anode through electron generation, apparently through their ability of metal-reduction. The case is the opposite with endoelectrogen; it consumes electric current at cathode through oxidation of metals [38,42]. They can either directly use membrane proteins/structures, pili, filaments, cytochromes, or secrete mediators for electron transfer; viz. Geobacter sulfurreducens uses pili as conductive wires for inter-cellular conduction of electrons. On the other hand, Shewanella spp. possesses both conductive filaments as well as mediators such as riboflavin. On the other hand, ferredoxin was found to work as mediators in bacteria belonging to Clostridia (Clostridium pasteurianum, C. ljungdahlii, and C. aceticum), Sporomusa ovata, Methanococcus maripaludis, etc. Interestingly, three different possible mediators-formate dehydrogenase, hydrogenase, and rubredoxin - have been found in sulfate-reducing bacteria (Desulfovibrio sp.) [38]. Theoretically, any biodegradable material can be transformed into energy and organic compounds [7]. The most widely exploited waste substrates include industrial wastewater effluents, waste biomass, inorganic substrates like ammonia, acid mine drainage, etc. [43]. However, co-operation among microbes are required to achieve the target. Thus, usually mixed cultures are used for this purpose [44]. The first sets of microbes are usually having high hydrolytic abilities to degrade complex wastes into simple substrates. The latter can be utilized by the second set of the electrochemically active bacterial population that can oxidize them in the anode chamber. Cathode based EFs differ from the one described above as for reduction of oxidized compounds customized systems must be used, which may or may not require external electric supply. Figure 2 shows the various mechanisms for electron transfer from electrodes to microorganisms. 

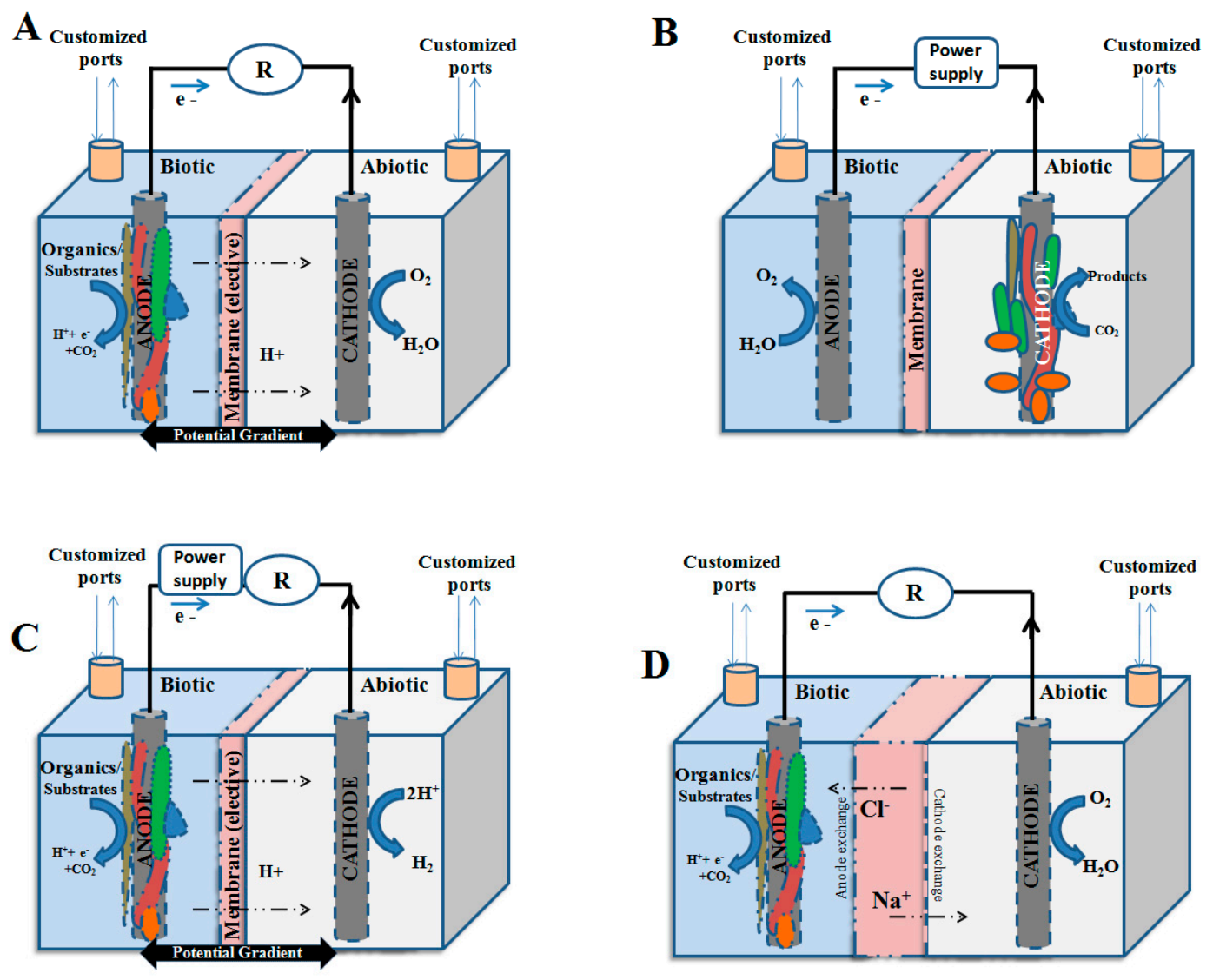

Figure 2. Variants of MES: (A) microbial fuel cells (MFC); (B) microbial electrolysis cell (MECs); (C) microbial electrosynthesis (MES); and (D) microbial desalination cells (MDCs).

Four general variants of EFs have been shown. The basic one is commonly known as MFC, which is used for direct generation of electricity from organic compounds. If MFC is supplied with external current to reduce the cathode potential, it becomes a MEC, wherein $\mathrm{H}_{2}$ and other products are generated in the cathode chamber [45]. If the MEC type system is used to remove contaminants (chlorinated compounds, uranium, etc.) from the solution, it is termed as microbial remediation cell (MRC), whereas it is known as microbial electrosynthesis (MES) if value-added chemicals are produced through microbial catalysis at the cathode (Table 1) [46-49]. An additional separating chamber can also be used between anode and cathode, which uses internal potential for desalination of water. The latter is known as microbial desalination cell (MDC) and is unique since it does not require external electricity to reduce the cathode potential [50-57]. There are many other variants available, which are customized for specific purposes but share the common principle [40]. 
Table 1. Variants of electro-fermenters and their potential applications in aid of bioenergy.

\begin{tabular}{|c|c|c|c|c|}
\hline Types & Substrates Used (Oxidation at Anode) & Reduction of Cathode & Major Output & References \\
\hline \multicolumn{5}{|c|}{$\begin{array}{ll}\text { Microbial Fuel Cells (MFC) } \\
\end{array}$} \\
\hline Tubular MFC & Glucose, Acetate, wastewater & $\mathrm{K}_{3}\left[\mathrm{Fe}(\mathrm{CN})_{6}\right]$ & Electric Current & [33] \\
\hline Up-flow MFC (UMFC) & Sucrose & $\mathrm{K}_{3}\left[\mathrm{Fe}(\mathrm{CN})_{6}\right], \mathrm{O}_{2}$ & Electric Current & {$[34,35]$} \\
\hline Up-flow anaerobic sludge blanket-MFC & Glucose & $\mathrm{O}_{2}$ & Electric Current & [36] \\
\hline Baffled air-cathode-MFC & Glucose, corn-stover hydrolysates & $\mathrm{O}_{2}$ & Electric Current & [37] \\
\hline Stacked-MFC & $\mathrm{NaOAc}$ & $\mathrm{K}_{3}\left[\mathrm{Fe}(\mathrm{CN})_{6}\right]$ & Electric Current & [58] \\
\hline Microbial reverse electrodialysis cell (MRC) & $\mathrm{NaOAc}$ & $\mathrm{O}_{2}$ & Electric Current & [59] \\
\hline Microbial reverse-electrodialysis chemical-production cell (MRCC) & $\mathrm{NaOAc}$ & $\mathrm{O}_{2}$ & Electric Current, acid, alkali & [46] \\
\hline \multicolumn{5}{|c|}{ Microbial Electrolysis Cells (MECs) } \\
\hline MEC-based systems for chemical production Microbial electrolysis cells (MECs) & Any biodegradable material & Proton & $\mathrm{H}_{2}, \mathrm{H}_{2} \mathrm{O}_{2}, \mathrm{CH}_{4}, \mathrm{NaOH}$ & {$[47-49,60]$} \\
\hline Bioelectro-chemically assisted microbial reactor (BEAMR) & Wastewater & Proton & $\mathrm{H}_{2}$ & [61] \\
\hline Solar-powered microbial electrolysis fuel (solar MEC) & Acetate & Proton & $\mathrm{H}_{2}$ & [62] \\
\hline Microbial reverse-electrodialysis electrolysis cell (MREC) & Acetate & Proton & $\mathrm{H}_{2}$ & [63] \\
\hline Submersible microbial electrolysis cell (SMEC) & Acetate & Proton & $\mathrm{H}_{2}$ & [64] \\
\hline Microbial electrolysis struvite-precipitation cell (MESC) & $\mathrm{NaOAc}^{\mathrm{a}}$ & Proton & $\mathrm{H}_{2}$, Struvite & [14] \\
\hline \multicolumn{5}{|c|}{ Microbial Electrosynthesis (MES) } \\
\hline $\begin{array}{l}\text { MES-based systems for chemical production } \\
\text { Solid state bio-electrofermentation system (SBES) }\end{array}$ & $\begin{array}{l}\text { Organic, } \mathrm{H}_{2} \text { sulfide, } \mathrm{H}_{2} \mathrm{O} \\
\text { Food wastes }\end{array}$ & $\begin{array}{c}\text { Acetate or other organics, } \mathrm{CO}_{2} \\
\mathrm{O}_{2}\end{array}$ & $\begin{array}{l}\text { Ethanol, acetate, 2-oxobutyrate, formate } \\
\text { Electricity, } \mathrm{H}_{2} \text {, Ethanol }\end{array}$ & $\begin{array}{c}{[65-68]} \\
{[6]}\end{array}$ \\
\hline \multicolumn{5}{|c|}{ Microbial Desalination Cells (MDCs) } \\
\hline MDC-based systems for water desalination and beneficial reuse & Any biodegradable material & $\mathrm{O}_{2}, \mathrm{~K}_{3}\left[\mathrm{Fe}(\mathrm{CN})_{6}\right]$, organics, or other oxidants & Desalination & [50] \\
\hline Microbial saline-wastewater electrolysis cell (MSC) & $\mathrm{NaOAc}$ & $\mathrm{H}_{2}$ & Treated saline wastewater, Electric Current & [69] \\
\hline Osmotic MDC & NaOAc, xylose, wastewater & $\mathrm{O}_{2}, \mathrm{~K}_{3}\left[\mathrm{Fe}(\mathrm{CN})_{6}\right]$, proton & Water desalination, Electric Current & [51] \\
\hline capacitive adsorption capability (cMDC) & $\mathrm{NaOAc}$ & $\mathrm{K}_{3}\left[\mathrm{Fe}(\mathrm{CN})_{6}\right]$ & Water desalination & [52] \\
\hline MDC packed with ion-exchange resin (R-MDC) & $\mathrm{NaOAc}$ & $\mathrm{O}_{2}$ & Water desalination, Electric Current & [53] \\
\hline Electrolysis-MDC & $\mathrm{NaOAc}$ & Proton & $\mathrm{H}_{2}$, water desalination & [54] \\
\hline Microbial electrolysis desalination and chemical production cell (MEDCC) & $\mathrm{NaOAc}$ & $\mathrm{O}_{2}$ & Water desalination, $\mathrm{NaOH}, \mathrm{HCl}$ & [55] \\
\hline Submerged MDC - denitrification cell (SMDDC) & $\mathrm{NaOAc}$ & Nitrate & Electric Current, $\mathrm{N}_{2}$ & [41] \\
\hline Stacked microbial desalination cell (SMDC) & $\mathrm{NaOAc}$ & $\mathrm{O}_{2}$ & Water desalination, Electric Current & [56] \\
\hline Upflow microbial desalination cell (UMDC) & $\mathrm{NaOAc}$ & $\mathrm{O}_{2}$ & Water desalination, Electric Current & [57] \\
\hline
\end{tabular}




\section{Electro-Fermentation in Aid of}

\subsection{Hydrogen}

Hydrogen is considered as the clean source of energy and has the potential to replace fossil fuel based energy sources [60,70]. It has attracted considerable global interest in the past few decades; however, its large-scale production through biological routes is limited due to expensive feed material and process costs [71]. The theoretical yield $4 \mathrm{~mol} / \mathrm{mol}$ can be achieved using dark fermentation that further limits the up-scaling at larger scale [60]. However, it was found that integrating such process using anaerobic MEC could enhance the $\mathrm{H}_{2}$ yield up to 4-folds. The common metabolism during dark fermentation through acetate or butyrate follows the following reaction:

$$
\begin{gathered}
\mathrm{C}_{6} \mathrm{H}_{12} \mathrm{O}_{6}+2 \mathrm{H}_{2} \mathrm{O} \rightarrow 4 \mathrm{H}_{2}+2 \mathrm{CO}_{2}+2 \mathrm{C}_{2} \mathrm{H}_{4} \mathrm{O}_{2} \\
\mathrm{C}_{6} \mathrm{H}_{12} \mathrm{O}_{6} \rightarrow 2 \mathrm{H}_{2}+2 \mathrm{CO}_{2}+\mathrm{C}_{4} \mathrm{H}_{8} \mathrm{O}_{2} .
\end{gathered}
$$

This limits the achievable $\mathrm{H}_{2}$ yield to $2 \mathrm{~mol} / \mathrm{mol}$ and $4 \mathrm{~mol} / \mathrm{mol}$ with butyrate and acetate as an end-product, respectively [60]. Integrating this process with an MEC using Geobacter, Shewanella, Pseudomonas, etc. leads to produce $\mathrm{H}_{2}$ from protons and electrons produced by microbes as shown below:

$$
\begin{gathered}
\text { Anode: } \mathrm{C}_{2} \mathrm{H}_{4} \mathrm{O}_{2}+2 \mathrm{H}_{2} \mathrm{O} \rightarrow 2 \mathrm{CO}_{2}+8 \mathrm{e}^{-}+8 \mathrm{H}^{+}, \\
\text {Cathode: } 8 \mathrm{H}^{+}+8 \mathrm{e}^{-} \rightarrow 4 \mathrm{H}_{2} .
\end{gathered}
$$

Acetate is the simplest substrate that produces $\mathrm{H}_{2}$ in MEC systems (Table 1). In addition, hydrogen-producing bioreactor effluents comprise a great quantity of intermediate metabolites (VFA), which can be considered as an alternative to the synthetic substrate for hydrogen production in MECs [24]. In this way, MECs can be effectively integrated with a hydrogen producing bioreactor to enhance the overall $\mathrm{H}_{2}$ yield, which makes the process economically more viable. Moreover, effluents from $\mathrm{CH}_{4}$ producing bioreactor can also be used as potential feedstock in $\mathrm{MEC}$ for $\mathrm{H}_{2}$ production. In MEC systems, $\mathrm{H}_{2}$ evolution at cathode using acetate and electrogenic bacteria $\left(\mathrm{E}_{\mathrm{An}} \cong 0.2 \mathrm{~V}\right)$ is insufficient at the cathode $\left(\mathrm{E}_{\mathrm{cell}}=-0.414 \mathrm{~V}, \mathrm{pH}=7\right)$. It was observed that producing $\mathrm{H}_{2}$ on the cathode at MEC requires very low voltage as compared to direct electrolysis of water. In addition, the use of the complete anaerobic condition increases the coulombic efficiency of the process. By this approach, a maximum yield of $11 \mathrm{~mol} \mathrm{H}_{2} / \mathrm{mol}$ glucose was obtained at the rate of $1 \mathrm{~m}^{3} \mathrm{H}_{2} /$ day $/ \mathrm{m}^{3}$ in the reactor. A novel system for simultaneous $\mathrm{H}_{2}$ and struvite $\left(\mathrm{MgNH}_{4} \mathrm{PO}_{4} \cdot 6 \mathrm{H}_{2} \mathrm{O}\right)$ generation was studied on the principle that struvite crystallization occurs at the cathode during a bioelectrochemical reaction in a single chamber MEC and was termed as MESC [14].

Hydrogen generation rate can be significantly improved by eliminating membranes from the dual chamber MEC. However, it also led to the consumption of $\mathrm{H}_{2}$ by methanogens to produce $\mathrm{CH}_{4}$. During MEC operation, methanogens compete directly with exoelectrogenic biocatalyst for substrate and also consume $\mathrm{H}_{2}$, which adversely affect the overall process efficiency [2,72]. In addition, purity of $\mathrm{H}_{2}$ generation in the MECs is also greatly influenced by hydrogenotrophic methanogens (Table 2). The addition of methanogen inhibitors or exposing the reactor to the aerobic condition may help to a certain extent, but it remains a major hurdle in an $\mathrm{H}_{2}$ generation by MECs [64]. Another limitation of this process is the use of expensive metal catalysts at the cathode.

In this context, a single-chambered MEC was used with acidogenic effluent (VFA rich) of an $\mathrm{H}_{2}$ production process to recover more $\mathrm{H}_{2}$ by applying $0.6 \mathrm{~V}$ (external) to the system with a concomitant utilization of $68 \%$ VFAs [73]. A wide variety of electrode materials (copper, platinum, graphite, etc.) were used as a potential electrode material in MECs for $\mathrm{H}_{2}$ production. However, electrically highly conductive electrode materials could be more effective in MECs for efficient $\mathrm{H}_{2}$ production $[61,62,74]$. 
Table 2. Reported examples of bioelectrochemical system for valuable products.

\begin{tabular}{|c|c|c|c|c|c|c|c|c|c|}
\hline \multirow{2}{*}{ Type } & \multirow{2}{*}{ Inoculum } & \multirow{2}{*}{ Substrate } & \multirow{2}{*}{ Potential (V) } & \multirow{2}{*}{ Product A } & \multirow{2}{*}{ Product B } & \multicolumn{2}{|c|}{ Yield of } & \multirow{2}{*}{ Remarks } & \multirow{2}{*}{ References } \\
\hline & & & & & & Product A & Product B & & \\
\hline MEC & Enriched mixed culture & $\mathrm{CO}_{2}$ & $-0.1 \mathrm{~V}$ & $\mathrm{CH}_{4}$ & 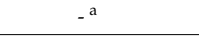 & $4.5 \mathrm{~L} \mathrm{~m}^{-2} \mathrm{~d}^{-1}$ & - & $80 \%$ energy efficiency & [47] \\
\hline MEC & Enriched mixed culture & $\mathrm{CO}_{2}$ & $-0.9 \mathrm{~V}$ & $\mathrm{CH}_{4}$ & - & $9.2 \mathrm{~L} \mathrm{~m}^{-2} \mathrm{~d}^{-1}$ & - & $\begin{array}{l}\text { high conversion rates } \\
\left(0.055 \mathrm{mmol} \mathrm{d}^{-1} \mathrm{mg} \mathrm{VSS}^{-1}\right)\end{array}$ & [75] \\
\hline BES & WWTP sludge & $\mathrm{CO}_{2}$ & -1 to $-1.15 \mathrm{~V}$ & Acetate & $\mathrm{CH}_{4}$ & $94.73 \mathrm{mg} \mathrm{d}^{-1}$ & $129.32 \mathrm{~mL} \mathrm{~d}^{-1}$ & $97 \%$ current capture efficiency & [76] \\
\hline MES & Acclimatized acetogens & $\mathrm{CO}_{2}$ & $-0.59 \mathrm{~V}$ & Acetate & $\mathrm{H}_{2}$ & $1.04 \mathrm{~g} \mathrm{~L}^{-1} \mathrm{~d}^{-1}$ & $0.2 \mathrm{~g} \mathrm{~L}^{-1} \mathrm{~d}^{-1}$ & $\begin{array}{l}\text { Stabile, resilient, and improved } \\
\text { performance over long-term operation }\end{array}$ & [77] \\
\hline BES & $\begin{array}{l}\text { Enriched electroactive } \\
\text { mixed culture biofilm }\end{array}$ & $\mathrm{CO}_{2}$ & $-1.1 \mathrm{~V}$ & Acetate & $\mathrm{H}_{2}$ & $2.35 \mathrm{mM} \mathrm{d}^{-1}$ & $<0.24 \mathrm{mM} \mathrm{d}^{-1}$ & $\begin{array}{l}\text { Cathode potential was identified as } \\
\text { a critical factor }\end{array}$ & [78] \\
\hline BES & $\begin{array}{l}\text { Enriched electroactive } \\
\text { mixed culture biofilm }\end{array}$ & $\mathrm{CO}_{2}$ & $-1.1 \mathrm{~V}$ & Acetate & $\mathrm{CH}_{4}$ & $0.62 \mathrm{mM} \mathrm{d}^{-1}$ & $1.9 \mathrm{mM} \mathrm{d}^{-1}$ & $\begin{array}{l}\text { Absence of methanogen inhibitor led to } \\
\text { methane production }\end{array}$ & [78] \\
\hline BES & $\begin{array}{l}\text { Clostridium pasteurianum } \\
\text { DSM525 } \\
\end{array}$ & Glycerol & $0.045 \mathrm{~V}$ & 1,3-Propanediol & Butanol & $93 \mathrm{mM}$ & $58 \mathrm{mM}$ & $\begin{array}{l}\text { Current consumption leads to } \\
\text { metabolic shift }\end{array}$ & [79] \\
\hline BES & Enriched mixed culture & Glycerol & $-0.9 \mathrm{~V}$ & 1,3-Propanediol & $\mathrm{H}_{2}$ and $\mathrm{CH}_{4}$ & $0.8 \mathrm{mM} \mathrm{L}^{-1} \mathrm{~h}^{-1}$ & - & $\begin{array}{l}\text { Direct } \mathrm{H}_{2} \text { supply enhances } 13-\mathrm{PDO} \\
\text { synthesis by releasing reduced } \mathrm{H}_{2} \\
\text { during the pyruvate decarboxylation. }\end{array}$ & [80] \\
\hline BES & Enriched mixed culture & Glycerol & -0.8 to $-1.1 \mathrm{~V}$ & 1,3-Propanediol & - & $42 \mathrm{~g} \mathrm{~L}^{-1}$ & - & $\begin{array}{l}6 \text { times higher } 1,3-\mathrm{PDO} \text { production } \\
\text { compared to non-BES fermentation; no } \\
\text { current supply leads to domination by } \\
\text { Lactobacillus producing lactic acid }\end{array}$ & [81] \\
\hline BES & $\begin{array}{l}\text { Clostridium pasteurianum } \\
\text { DSM525 }\end{array}$ & Glucose & $0.045 \mathrm{~V}$ & Butanol & Acetate/Butyrate & $1.2 \mathrm{mM} \mathrm{h}^{-1}$ & $3.2 \mathrm{mM} \mathrm{h}^{-1} / 3.7 \mathrm{mM} \mathrm{h}^{-1}$ & $\begin{array}{l}\text { In BES, } \mathrm{e}^{-} \text {uptake by C. pasteurianum led } \\
\text { to a metabolic shift where reduced } \\
\text { nicotinamide adenine dinucleotide } \\
\text { (NADH) consumption was quick by } \\
\text { butanol production instead of acids. }\end{array}$ & [79] \\
\hline MES & Clostridium ljungdahlii & $\mathrm{CO}_{2}$ & $-1.1 \mathrm{~V}$ & Ethanol/Acetate & $\mathrm{H}_{2}$ & $\sim 100 \mathrm{mg} \mathrm{L}^{-1} / 19.19 \mathrm{~g} \mathrm{~m}^{-2} \mathrm{~d}^{-1}$ & - & $\begin{array}{l}\mathrm{H}_{2} \text { production may stimulate planktonic } \\
\text { bacteria rather than cathodic-biofilm. }\end{array}$ & [82] \\
\hline MES & Mixed culture & $\mathrm{CO}_{2}$ & $-1.1 \mathrm{~V}$ & Acetate & $\mathrm{H}_{2} / \mathrm{CH}_{4}$ & $37.89 \mathrm{~g} \mathrm{~m}^{-2} \mathrm{~d}^{-1}$ & - & $\begin{array}{l}\mathrm{H}_{2} \text { production is possibly a quick mode } \\
\text { of transferring } \mathrm{e}^{-} \text {to the biocatalysts. }\end{array}$ & [82] \\
\hline BES & Enriched mixed culture & Acetate & $0.5 \mathrm{~V}$ & $\mathrm{H}_{2} \mathrm{O}_{2}$ & - & $1.9 \mathrm{Kg} \mathrm{m}^{-3} \mathrm{~d}^{-1}$ & - & $\begin{array}{l}\text { Low energy requirement of approx. } \\
0.93 \mathrm{kWh} / \mathrm{kg} \text { of } \mathrm{H}_{2} \mathrm{O}_{2}\end{array}$ & [49] \\
\hline MES & C. ljungdahlii DSM13528 & $\mathrm{CO}_{2}$ & $-0.6 \mathrm{~V}$ & Acetate & Oxobutyrate & $\sim 105 \mu \mathrm{M}$ Acetate & - & $\begin{array}{l}\text { Engineered strains of C. ljungdahlii } \\
\text { capable of electrosynthesis could } \\
\text { become a potential candidate for } \\
\text { industrial biofuel production }\end{array}$ & [67] \\
\hline MES & Moorella thermoacetica & $\mathrm{CO}_{2}$ & $-0.6 \mathrm{~V}$ & Acetate & - & $\sim 90 \mu \mathrm{M}$ Acetate & - & $\begin{array}{l}>80 \% \text { conversion efficiency by } \\
\text { M. thermoacetica }\end{array}$ & [67] \\
\hline BES & Mixed cultures & Glucose & - & Electricity & Polyhydroxylkanoate & $512 \mathrm{mV}$ & $<2 \%$ dry cell mass & Higher degradation at cathode & [83] \\
\hline $\begin{array}{l}\text { single } \\
\text { chambered MEC }\end{array}$ & $\begin{array}{l}\text { Acid-shock pretreated } \\
\text { anaerobic consortium }\end{array}$ & $\begin{array}{l}\text { Acidogenic spent } \\
\text { wash effluents } \\
+0.6 \mathrm{~V}\end{array}$ & $0.6 \mathrm{~V}$ & $\mathrm{H}_{2}$ & - & $\begin{array}{l}39.35 \mathrm{~mL} \text { at the rate } \\
\text { of } 0.057 \mathrm{mmol} / \mathrm{h}\end{array}$ & - & $\begin{array}{l}68 \% \text { VFA utilization; Additional } \mathrm{H}_{2} \\
\text { recovery utilizing VFA rich effluents }\end{array}$ & [73] \\
\hline
\end{tabular}


Table 2. Cont.

\begin{tabular}{|c|c|c|c|c|c|c|c|c|c|}
\hline \multirow{2}{*}{ Type } & \multirow{2}{*}{ Inoculum } & \multirow{2}{*}{ Substrate } & \multirow{2}{*}{ Potential (V) } & \multirow{2}{*}{ Product A } & \multirow{2}{*}{ Product B } & \multicolumn{2}{|c|}{ Yield of } & \multirow{2}{*}{ Remarks } & \multirow{2}{*}{ References } \\
\hline & & & & & & Product $\mathbf{A}$ & Product B & & \\
\hline $\begin{array}{c}\text { Double } \\
\text { chambered BES }\end{array}$ & $\begin{array}{c}\text { Enriched culture of } \\
\text { homoacetogenic bacteria }\end{array}$ & $\mathrm{CO}_{2}$ & $-0.8 \mathrm{~V}$ & Acetic acid & - & $12.57 \mathrm{mM}$ & - & $\begin{array}{l}\text { Enrichment of biocatalysts improved } \\
\text { the yield }\end{array}$ & [84] \\
\hline Stacked MFC & $\begin{array}{l}\text { Aerobic and anaerobic } \\
\text { sludge mixture }\end{array}$ & sodium acetate & - & Electricity & - & $258 \mathrm{~W} \mathrm{~m}^{-3}$ & - & $\begin{array}{l}\text { Coulombic efficiency } 71.6 \% \text { or substrate } \\
\text { to electricity conversion of } 4.7 \mathrm{~g} \\
\text { COD L }^{-1} \mathrm{~d}^{-1}\end{array}$ & [58] \\
\hline $\begin{array}{l}\text { MEC without } \\
\text { membrane }\end{array}$ & Acetate-fed mixed culture & sodium acetate & $0.8 \mathrm{~V}$ & $\mathrm{H}_{2}$ & $\mathrm{CH}_{4}$ & $3.12 \mathrm{~m}^{3} \mathrm{H}_{2} / \mathrm{m}^{3}$ reactor per day & $1.9 \%$ of the total gas & $\begin{array}{l}\text { High } \mathrm{H}_{2} \text { is possible by membrane-less } \\
\text { MFC in a single chamber system }\end{array}$ & [72] \\
\hline MEC & $\begin{array}{c}\text { Effluent of } \\
\text { wastewater plant }\end{array}$ & glucose & $1.0 \mathrm{~V}$ & $\mathrm{CH}_{4}$ & - & $408.3 \mathrm{mLCH}_{4} / \mathrm{g} \mathrm{COD}$ & - & $30.3 \%$ higher than in the control & [85] \\
\hline MFC & $\begin{array}{l}\text { Aerobic and anaerobic } \\
\text { sludge mixture }\end{array}$ & Acetate & $0.6 \mathrm{~V}$ & $\mathrm{CH}_{4}$ & - & $0.41 \mathrm{~mol} / \mathrm{mol}$ of acetate & - & $\begin{array}{l}\text { lower partial pressure of } \mathrm{H}_{2} \\
\text { can improve the cathodic reduction } \\
\text { thermodynamics }\end{array}$ & [86] \\
\hline
\end{tabular}

${ }^{a}$ Not reported; BES: Bioelectrochemical system; MEC: Microbial electrolysis cell; MES: Microbial electrosynthesis systems; WWTP: Wastewater treatment plant; COD: Chemical oxygen demand. 


\subsection{Biogas}

Biomethane is usually produced by methanogens using acetate, formate, and hydrogen obtained from pure compounds or various biowastes as substrates in an anaerobic reactor $[87,88]$. The first route (acetate substrate) is operated by acetoclastic methanogens while the second route (using $\mathrm{H}_{2}$ substrate) is by hydrogenotrophic methanogenesis [89]. Factors affecting biogas production include $\mathrm{pH}$, hydraulic retention time, substrate load, temperature, $\mathrm{C} / \mathrm{N}$ ratio, acclimation period, and substrate composition $[47,90]$. For any given experimental setup controlling two or more such parameters is easy on a lab scale, while on a large scale controlling parameters, particularly the feed composition is difficult to maintain over a long period of time. Recently, an agricultural biogas plant was used to demonstrate that optimized feed composition based on a detailed database and the linear program model could be helpful in achieving consistency in running similar biogas plants [90]. However, it was emphasized that optimization of such feedstock is promising but limited by the high organic contents contributed by maize and grass silage that governs the majority of the biogas produced. Any transient decrease in the feedstock may raise the energy crops proportion within the substrates, leading to higher biogas evolution. The requirement of land to grow energy crops is comparatively less than food-crops; therefore, a systematic economic evaluation of any given agricultural biogas plant is desirable $[90,91]$. Besides the above-mentioned major factors, the changes in microbial communities during the operation cycle have been studied. Acclimatization of the mixed cultures (defined or undefined) along with other co-feeding strategies has shown potential in enhancing the consistency and performance [89,92]. In contrast, MEC based EF could provide various advantages over the conventional biogas production. During this process, methanogens directly accept electrons (from cathode) and are reported to produce $\mathrm{CH}_{4}$ largely from $\mathrm{H}_{2}$ gas generated at the cathode and partly through acetate conversion [7]. Therefore, about $86 \%$ enriched $\mathrm{CH}_{4}$ production was observed compared to conventional anaerobic digestion in addition to the consumption of $\mathrm{CO}_{2}$ during the process [75]. The thermodynamically plausible process of $\mathrm{CH}_{4}$ generation through $\mathrm{CO}_{2}$ reduction at $0.169 \mathrm{~V}, \mathrm{pH} 7$ had also been proposed:

$$
\begin{gathered}
\mathrm{C}_{2} \mathrm{H}_{4} \mathrm{O}_{2} \rightarrow \mathrm{CH}_{4}+\mathrm{CO}_{2} \text { [Acetoclastic Methanogenesis], } \\
4 \mathrm{H}_{2}+\mathrm{CO}_{2} \rightarrow \\
\mathrm{CH}_{4}+2 \mathrm{H}_{2} \mathrm{O} \text { [Hydrogenotrophic Methanogenesis], } \\
\mathrm{CO}_{2}+8 \mathrm{H}^{+}+8 \mathrm{e}^{-} \rightarrow \mathrm{CH}_{4}+2 \mathrm{H}_{2} \mathrm{O} .
\end{gathered}
$$

In contrast to anaerobic digestion, it was found that, in the MEC, most of the $\mathrm{CH}_{4}$ produced during the process are derived from $\mathrm{H}_{2}$. However, the source of $\mathrm{CH}_{4}$ in $\mathrm{MEC}$ (acetate or $\mathrm{H}_{2}$ ) is yet to be clearly understood. Methanogenic conversion of $\mathrm{H}_{2}$ to $\mathrm{CH}_{4}$ leads to specific thermodynamic loss of energy $(\sim 15 \%)$. Thus, it was suggested that linking MECs to anaerobic digestion process may become a viable option for bioenergy [93]. Organic loading, long reaction time, ammonia levels and higher substrate concentrations are the key to enhanced methane production. Up to $40 \%$ enrichment of acetoclastic methanogen population was observed during an anaerobic digestion-MEC, which was proposed to efficiently degrade the organic material and convert VFA to $\mathrm{CH}_{4}[85,94]$. Methanobacterium palustre was among the first few organisms studied for the $\mathrm{CH}_{4}$ generation with an abiotic anode and biocathode [47]. In this process, biotic carbon cathode favors $\mathrm{CH}_{4}$ generation while plain cathode leads to $\mathrm{H}_{2}$ production (Table 2). Here, current seems to play a major role. At a supply of $<0.5 \mathrm{~V}$, $\mathrm{H}_{2}$ level decreases while $\mathrm{CH}_{4}$ concentration increases [72,95]. On the other hand, when the applied voltage was $>0.7 \mathrm{~V}, \mathrm{H}_{2}$ levels were restored [95]. Here, carbonate concentration and medium $\mathrm{pH}$ shows an important role in shifting the metabolism from $\mathrm{H}_{2}$ ( $\downarrow$ carbonate and $\mathrm{pH}$ ) to $\mathrm{CH}_{4}$ ( $\uparrow$ carbonate and $\mathrm{pH}$ ) [89]. It was demonstrated that electromethanogenesis can use electricity generated through renewable resources into biofuel with simultaneous capturing of carbon dioxide. Since $\mathrm{CH}_{4}$ generation is quite unavoidable in the $\mathrm{H}_{2}$ producing MEC, the purification of $\mathrm{H}_{2}$ becomes quite expensive leading to higher production cost. Thus, production of $\mathrm{CH}_{4}$ becomes feasible through electromethanogenesis. Additionally, it is easy to store, compress, and transport. Nowadays, the research focus is more 
on developing membrane-less MECs. A two-chambered MEC present loss of concentration due to the accumulation of $\left[\mathrm{H}^{+}\right]$or $\left[\mathrm{OH}^{-}\right]$. Production of methane through MEC provides the additional advantage of sludge loss and alleviating aeration cost [93]. It was also demonstrated that, in a single chamber $\mathrm{MEC}, \mathrm{CH}_{4}$ production is indeed linked with the current generation and $\mathrm{H}_{2}$ production instead of acetoclastic methanogenesis [89]. The work of Clauwaert et al. showed that the $\mathrm{CH}_{4}$ generation increased up to $0.41 \mathrm{~mol} / \mathrm{mol}$ acetate when two-chamber MEC was used [86]. Later, they developed a membrane-less MEC using graphite granule electrodes that helped in producing $\mathrm{CH}_{4}$ as the main product under MEC operated with the carbonate-limited acidified medium [96]. However, limitation of methane solubility at different temperature and $\mathrm{pH}$ conditions remains similar to that of conventional fermentation. Progress is underway to exploit biowastes for $\mathrm{CH}_{4}$ generation through the bioelectrochemical system. In this context, garbage slurry, food wastes, and wastewater have been explored as a substrate for biogas production [94,97,98]. MEC works well on low-strength wastewater and must be supported by anaerobic digesters when the feed has very high-strength wastewater or organic load. One must understand that MEC based technology (developed to date) may not potentially work as a standalone process and thus do not have the desired capacity to replace existing methodology, rather it will require the support of other methods to achieve higher efficiency. The integrative bioprocesses may prove helpful in the near future to treat wastes and wastewater while producing bioenergy in a sustainable manner.

\subsection{1,3-Propanediol}

1,3-Propanediol (PDO) is an industrially important chemical that is used in cosmetics, resins, solvents, polymers, etc. Its biological production is usually carried out using glycerol as feed. In recent years, the flourishing biodiesel industry resulted in unmanageable quantities of glycerol rich effluents [99]. In addition, glycerol has high electron content (4.7 moles $\mathrm{e}^{-} / \mathrm{mol}$ of carbon). There are plenty of microbes possessing the ability to bioconvert glycerol into PDO. The recent advancements in cathodic EFs have led to enhanced PDO yield with the following advantages: (i) direct electron dissipation into PDO synthesis; (ii) selection of bacterial population adapted to reduced condition; and (iii) enhancing PDO generation as a sole NADH dissipating pathway [79]. Few studies have been performed on mixed culture glycerol $\mathrm{EF}$ using the strong negative potential of $-1.14 \mathrm{~V}$ to achieve PDO production of $0.50 \mathrm{~mol} / \mathrm{mol}$ glycerol, which is 2-fold higher than batch fermentation [80,81]. In another study where the cathodic current was supplied, the PDO production was found to be positively influenced by the electron input leading to a yield of $0.51 \mathrm{~mol} / \mathrm{mol}$ glycerol. In a fed-batch system equipped with $-1.34 \mathrm{~V}$ at the cathode, the yield could reach $0.46 \mathrm{~mol} / \mathrm{mol}$ glycerol. Thus, the EF strategy clearly out beats the conventional fermentation by applying minimal external current supply. However, the small amount of $\mathrm{H}_{2}$ produced due to water at cathode makes it difficult to assess the predominant effect of EF. In addition, while working with Geobacter sulfurreducens, it was observed that the fermentation pattern, as well as the microbial population could be influenced by EFs. A similar observation was made with C. pasteurianum that showed $21 \%$ shift in NADH-consumption to produce PDO using glycerol as substrate [79]. Such study increases the possibilities of efficient production of electron dense compounds using small quantities of electricity.

\subsection{Alcohols}

The global demand for alcohols especially ethanol as a potent energy alternative continues to surge [100]. Alcohols have traditionally been produced through various fermentation strategies that usually require $48-90 \mathrm{~h}$ to achieve maximum concentration. With the advancements in strain improvement programs, high gravity ethanol fermentation (ethanol tolerance of 10-12\%) can be achieved with an initial sugar feed of $>180 \mathrm{~g} / \mathrm{L}$. Recently, MFC was modified to BES, which can use the reduction mechanism at the cathode to be used for electrogenesis as well as producing valuable end products such as acetate, aldehydes, ethanol, etc. [6]. The EF strategy had been adopted to govern the glucose consumption in Saccharomyces cerevisiae. This process involved an external supply 
of $-1.5 \mathrm{~V}$ to the reactor containing S. cerevisiae and $120 \mathrm{~g} / \mathrm{L}$ of glucose. The strain grew faster reportedly due to the electrons supplied through the cathode, which leads to achieving $53 \mathrm{~g} / \mathrm{L}$ ethanol yield after $50 \mathrm{~h}$ of incubation [101]. Similarly, in another experiment electrochemical-electrostatic technique in a transistor-like device was used for short-term ethanol production by S. cerevisiae [102]. On the other hand, Zymomonas mobilis is a well-known organism for industrial ethanol production that can ferment sugars through the Enter-Doudoroff pathway and tolerate higher ethanol concentrations. Under electrochemical fermentation equipped with the cathode (DC $-3 \mathrm{~V})$ and air anode, Z. mobilis showed higher biomass, as well as 50\% increased ethanol production [103]. In contrast, electrostatic fermentation could enhance the ethanol yield up to 2-fold with a concomitant decline (only $24 \mathrm{~h}$ of fermentation) in the operation period. In such process, complete fermentation of glucose was observed by S. cerevisiae leading to $14 \% v / v$ ethanol in $20 \mathrm{~h}$ of incubation without the requirement of external electricity [100]. Besides yeasts, engineered Shewanella oneidensis (a known exoelectrogen) was used for oxidization of glycerol into ethanol through deposition of reducing equivalents at the anode. Similarly, glucose was successfully converted to more reduced products like ethanol and butanol by Clostridium acetobutylicum (Table 2). Another bacterium, C. thermocellum, was shown to display a considerable shift in the concentration of metabolites when an external potential of $-1.5 \mathrm{~V}$ was provided. This leads to $61 \%$ enhancement in the overall ethanol yield, increasing the potential negatively influences the process [101]. Similarly, C. pasteurianum under electrochemical system displayed a shift in the metabolic pathway for enhanced production of butanol [79]. Besides glucose, other substrates such as acetate, glycerol, $\mathrm{CO}_{2}$, butyrate, etc. have also been used for alcohol production [66,79]. A wild-type strain of C. pasteurianum was able to accept electrons from cathode during heterotrophic growth on glucose as well as glycerol leading to NADH-consuming compounds such as butanol and PDO [79]. Another species, Clostridium ljungdahlii was also found to convert $\mathrm{CO}_{2}$ into acetate while ethanol, methane, and hydrogen were also produced in minor quantities [82]. Reduction of acetate to ethanol can also be achieved using methyl viologen (MV) mediator in the cathode chamber. The role of mediator was to inhibit side reactions (i.e., methanogenesis) and thus enhance the ethanol production. A similar set-up can be utilized for butanol production using butyrate as a substrate and MV as a mediator [93]. An engineered strain of Ralstonia eutropha was found to reduce $\mathrm{CO}_{2}$ using $\mathrm{H}_{2}$ obtained from water splitting (from the bioelectrochemical system) to produce up to $0.216 \mathrm{~g} / \mathrm{L}$ of isopropanol [104]. $\mathrm{CO}_{2}$ fixation at the cathode mimics the natural photosynthesis and holds a great potential in future [79]:

$$
\mathrm{nCO}_{2}+\left(6_{\mathrm{n}}+2\right)\left(\mathrm{e}^{-1}+\mathrm{H}^{+}\right) \rightarrow \mathrm{C}_{\mathrm{n}} \mathrm{H}_{2 \mathrm{n}+2}+2 \mathrm{nH}_{2} \mathrm{O}
$$

If a good redox link is established among electrode and the bacteria, the EFs become advantageous over conventional fermentation by (i) enhanced process control; (ii) lower biomass yields; and (iii) efficient electron distribution. However, for enhanced ethanol production in an EF non-mediated reduction at cathode must be developed, possibly by growing microbes at the cathode [93]. The competition among traditional and advanced biofuels will affect their large-scale production since they depend largely upon the limited land resources, crops (food/non-food), and lignocellulosic wastes. An EF strategy can contribute both to a more efficient energy production and livestock feed (indirectly to food supply) with the use of the byproducts of bioethanol production [18]. An integrative process was also developed combining bioethanol production along with MEC to produce hydrogen with concurrent degradation of phenolic compounds and its derivatives (furfurals) from the by-products of bioethanol (Figure 3). It was estimated that one ton of wheat straw can generate up to $190 \mathrm{~kg}$ of ethanol, $23 \mathrm{~kg}$ of hydrogen, and $140 \mathrm{~kg}$ of lignin [105].

The yield would depend on the cellulose and hemicellulose content of the wastes being used. It was proposed that such a process may lead to around $83 \%$ energy recovery with a gross value of 200 Euro/ton of wheat straw (including lignin). 


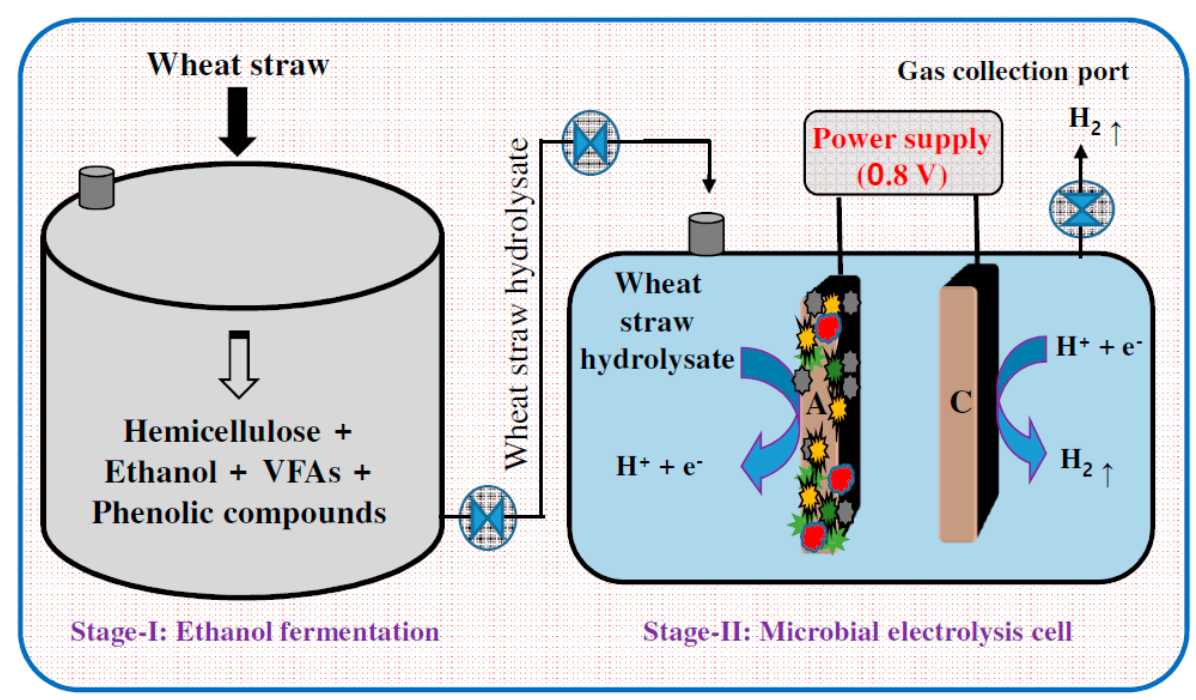

Figure 3. Schematic design of a two-stage process integration scheme, i.e., integration of microbial electrolysis cell (MEC) with ethanol fermentation (from wheat straw) process to harvest bioenergy (ethanol and hydrogen) with concurrent waste remediation.

\subsection{Polyhydroxyalkanoates}

PHAs are the only polyesters of biological origin that has promising features to replace fossil fuel-based plastics. In nature, PHAs are produced by bacteria in the form of lipid granules under nutrition imbalance conditions and acts as a reserve carbon source [106-108]. Thermomechanical properties of this polymer are quite comparable to synthetic plastics with an added advantage that it is biodegradable and biocompatible in nature. However, large-scale PHA production is still uneconomical and requires more research effort towards reducing the production cost by employing cheap carbon sources as feed and using green solvents for extraction. It had been emphasized to produce value added side-products during the PHA production such that the overall production cost gets minimized. Some of the reported examples include $\mathrm{PHA}_{2} \mathrm{H}_{2}$, PHA-carotenoids, PHA-rhamnolipids, etc. [108-110]. With the growing advancements in BES, it was realized that biocathode can be used for enhanced electrogenesis with concomitant production of PHA at the cathode [83]. Here, using synthetic water supplemented with glucose, the electrogenic activity, and PHA accumulation was recorded to be $512 \mathrm{mV}$ and $19 \% w / w$, respectively. Enriched mixed cultures from an anaerobic digester and the activated sludge unit were used at anode and cathode, respectively. Under microaerophilic environment, PHA accumulating organisms may act as a terminal electron acceptor at the cathode. Such strategies have multiple advantages of producing electricity, PHA, and wastewater treatment in a single fermentative reaction [83]. However, much research is required to improve the PHA yield in such processes, since at low PHA yield the extraction cost may increase.

\subsection{Integrative Approach of Utilizing EF in a Biorefinery Prospective}

Lignocellulosic biomass has emerged as the most promising substrates for bioenergy generation, provided efficient pretreatments methods are available. Such wastes, e.g., corn stover and straw usually consist of 30-40\% cellulose, $20-30 \%$ hemicellulose, and 15-20\% lignin [105]. Various individual sugars present in the lignocellulosic materials (glucose, cellobiose, xylose, arabinose, etc.) have been used for fermentative $\mathrm{H}_{2}, \mathrm{CH}_{4}$, PHA, ethanol, biodiesel, etc. through different strategies [105,109]. When MEC was linked with wheat straw hydrolysate after ethanol production, it was found to remove toxic compounds (furfurals) and successfully converted the residual sugars into hydrogen (13-24 g/kg straw). During this process, $96 \%$ of hemicellulose, $100 \%$ VFAs, and $50 \%$ of the phenolic compounds were utilized. This may allow water recirculation in biorefinery and alleviate the use of 
fresh water [105]. Co-production of various biofuels and organic compounds using wastes and $\mathrm{CO}_{2}$ as direct substrates indicates the promising future with MFC based technologies [58,76-78,84]. Similarly, an electrodialysis system was used to extract the organic acids produced during dark fermentation of glucose for $\mathrm{H}_{2}$ production by Escherichia coli. The extracted organics were later used as a potential nitrogen free carbon source for photo-fermentative $\mathrm{H}_{2}$ production by Rhodobacter sphaeroides [111]. Later, this process was successfully demonstrated on food waste hydrolysates [112]. Such extractive fermentation is anticipated to sustain indefinitely; however, membrane fouling, the requirement of constant ionic composition, $\mathrm{pH}$ imbalance, etc. are the major hurdles. MECs were also integrated with reverse electrodialysis called MRECs, which showed natural $\mathrm{H}_{2}$ generation due to the merging of the impulse from organic oxidation at the anode and energy of salinity gradient; in addition, the salt solutions can be constantly regenerated with waste heat $\left(\sim 38-40^{\circ} \mathrm{C}\right)[59,63]$. In a recent effort, solid state bio-electrofermentation system (SBES) was developed for the integrated production of electricity, $\mathrm{H}_{2}$, and ethanol on the basis of self-induced potential [6]. Here, food waste substrates were directly converted to multiple products with the help of anaerobic enriched cultures of acidogenic bacteria as biocatalyst in the SBES [6]. It has been emphasized that, for successful waste management, an intellectually designed BES could successfully convert actual organic wastes through integrated solid-state fermentation making the whole process sustainable.

\section{Limitations and Challenges for Electro-Fermentations}

The progress in EFs has advanced in recent years, both in terms of higher power output and increased efficiency [65,67-69]. However, a consensus is yet to be developed on the mechanism of electron transfer across the membrane and microbial surface. In an electrochemical cell, electrolytes are a major component that provides a path for proton to cross from anode to cathode chamber. Most commonly used electrolytes include Nafion, etc. In addition, the use of expensive separating membrane hinders the large-scale applications. Other major issues are low power densities, $\mathrm{pH}$ variations, ohmic voltage loss (due to ionic and electronic resistance), low transport across membranes, overpotential (due to mass transport resistance), oxidant and proton flux towards the bio-cathode, bacterial growth on membranes, turnover per cells, and lastly a uniform standard data reporting system (for worldwide acceptance and fast work on technological realization). Some possible alternatives are being explored to overcome this limitation. For example, Nafion can be replaced by soil/clay based electrolytes. In addition, mediators used during BES should be regenerated after the process, i.e., it must not be consumed in the reaction [66]. Call and Logan have developed a single chamber EF system, thereby leaving the necessity to use costly separating membranes [72]. The advantage of microbial electrosynthesis is the possible on-site use of current for bioproduction and its independence from agricultural lands. However, all of these practices are being explored only in lab scale and are yet to be tested in large scale. The actual large-scale implementation would require EFs to be used in stacks, but such configuration is highly vulnerable to cell reversal [93]. In an EF system, the power generation (density) decreases with increase in anode surface area. Thus, maintaining low internal resistance with an increase in the electroactive biomass, separation of the anode from the cathode, and the reactor design are the three major challenges in scaling-up the EF based process $[15,58,93]$. Overall, all these limitations are believed to increase the reactor design costs for long-term operation. Biocatalysis at both electrodes and its integration with other biorefinery models are some of the potential solutions. It has been estimated that to become commercially competitive and viable over anaerobic digestion, performance of the EF based system must exceed $500 \mathrm{~W} / \mathrm{m}^{3}$. Recent advancements and the research efforts being incurred in bioelectrofermentation holds the potential success of this technology in near future.

\section{Future Perspectives}

With the recent developments in EF technology, harvesting electricity using the waste of various origins seems an attractive option. The advances in microbial electrosynthesis have provided 
a myriad option to produce and/or extract useful chemicals from pure substrates as well as biowastes. Nevertheless, few critical issues such as $\mathrm{pH}$, high ohmic resistance, and overpotential are yet to be studied carefully for its successful implementation. Exploration of unique materials and microbes is of utmost importance for superior performance and attractive operating cost. In addition, integrating these processes with other biodegradation methods may lead to its successful utilization in developing waste biorefinery models for sustainable bioeconomy.

Acknowledgments: This research was supported by the National Research Foundation of Korea (NRF-2017R1A2B4002371). P.K. is thankful for the financial support provided by a Brain Korea 21 plus project grant from the National Research Foundation of Korea.

Author Contributions: P.K. and B.S. conceived and developed the manuscript; K.C., A.K., and E.S. performed the literature search, data analysis and helped in the preparation of Figures. P.K. and B.S. wrote the paper.

Conflicts of Interest: The authors declare no conflict of interest.

\section{References}

1. Deval, A.S.; Parikh, H.A.; Kadier, A.; Chandrasekhar, K.; Bhagwat, A.M.; Dikshit, A.K. Sequential microbial activities mediated bioelectricity production from distillery wastewater using bio-electrochemical system with simultaneous waste remediation. Int. J. Hydrogen Energy 2017, 42, 1130-1141. [CrossRef]

2. Kadier, A.; Kalil, M.S.; Abdeshahian, P.; Chandrasekhar, K.; Mohamed, A.; Azman, N.F.; Logroño, W.; Simayi, Y.; Hamid, A.A. Recent advances and emerging challenges in microbial electrolysis cells (MECs) for microbial production of hydrogen and value-added chemicals. Renew. Sustain. Energy Rev. 2016, 61, 501-525. [CrossRef]

3. Chandrasekhar, K.; Lee, Y.-J.; Lee, D.-W. Biohydrogen production: Strategies to improve process efficiency through microbial routes. Int. J. Mol. Sci. 2015, 16, 8266-8293. [CrossRef] [PubMed]

4. Chandrasekhar, K.; Venkata Mohan, S. Induced catabolic bio-electrohydrolysis of complex food waste by regulating external resistance for enhancing acidogenic biohydrogen production. Bioresour. Technol. 2014, 165, 372-382. [CrossRef] [PubMed]

5. Chandrasekhar, K.; Venkata Mohan, S. Bio-electrohydrolysis as a pretreatment strategy to catabolize complex food waste in closed circuitry: Function of electron flux to enhance acidogenic biohydrogen production. Int. J. Hydrogen Energy 2014, 39, 11411-11422. [CrossRef]

6. Chandrasekhar, K.; Amulya, K.; Venkata Mohan, S. Solid phase bio-electrofermentation of food waste to harvest value-added products associated with waste remediation. Waste Manag. 2015, 45, 57-65. [CrossRef] [PubMed]

7. Logan, B.E.; Rabaey, K. Conversion of wastes into bioelectricity and chemicals by using microbial electrochemical technologies. Science 2012, 337, 686-690. [CrossRef] [PubMed]

8. Sustainable Wastewater Treatment Systems: Distributed Resource Recovery for Industry. Available online: Www.cambrianinnovation.com (accessed on 11 January 2018).

9. Patil, S.A.; Gildemyn, S.; Pant, D.; Zengler, K.; Logan, B.E.; Rabaey, K. A logical data representation framework for electricity-driven bioproduction processes. Biotechnol. Adv. 2015, 33, 736-744. [CrossRef] [PubMed]

10. Plant-e Living Plants Generate Electricity. Available online: www.plant-e.com (accessed on 12 January 2018).

11. Global Water, Wastewater \& Reuse Solutions. Available online: www.fluencecorp.com (accessed on 12 January 2018).

12. Trapero, J.R.; Horcajada, L.; Linares, J.J.; Lobato, J. Is microbial fuel cell technology ready? An economic answer towards industrial commercialization. Appl. Energy 2017, 185, 698-707. [CrossRef]

13. What If Stranded Power Could Be Harnessed and Stored as Chemical Energy for Later Use? Available online: www.electrochaea.com (accessed on 11 January 2018).

14. Cusick, R.D.; Logan, B.E. Phosphate recovery as struvite within a single chamber microbial electrolysis cell. Bioresour. Technol. 2012, 107, 110-115. [CrossRef] [PubMed]

15. Fornero, J.J.; Rosenbaum, M.; Angenent, L.T. Electric power generation from municipal, food, and animal wastewaters using microbial fuel cells. Electroanalysis 2010, 22, 832-843. [CrossRef] 
16. Kadier, A.; Simayi, Y.; Chandrasekhar, K.; Ismail, M.; Kalil, M.S. Hydrogen gas production with an electroformed $\mathrm{Ni}$ mesh cathode catalysts in a single-chamber microbial electrolysis cell (MEC). Int. J. Hydrogen Energy 2015, 40, 14095-14103. [CrossRef]

17. Kadier, A.; Simayi, Y.; Abdeshahian, P.; Azman, N.F.; Chandrasekhar, K.; Kalil, M.S. A comprehensive review of microbial electrolysis cells (MEC) reactor designs and configurations for sustainable hydrogen gas production. Alex. Eng. J. 2016, 55, 427-443. [CrossRef]

18. Popp, J.; Harangi-Rákos, M.; Gabnai, Z.; Balogh, P.; Antal, G.; Bai, A. Biofuels and their co-products as livestock feed: Global economic and environmental implications. Molecules 2016, 21, 285. [CrossRef] [PubMed]

19. Galanakis, C.M. Recovery of high added-value components from food wastes: Conventional, emerging technologies and commercialized applications. Trends Food Sci. Technol. 2012, 26, 68-87. [CrossRef]

20. ElMekawy, A.; Srikanth, S.; Bajracharya, S.; Hegab, H.M.; Nigam, P.S.; Singh, A.; Mohan, S.V.; Pant, D. Food and agricultural wastes as substrates for bioelectrochemical system (BES): The synchronized recovery of sustainable energy and waste treatment. Food Res. Int. 2015, 73, 213-225. [CrossRef]

21. Mohan, S.V.; Chandrasekhar, K. Solid phase microbial fuel cell (SMFC) for harnessing bioelectricity from composite food waste fermentation: Influence of electrode assembly and buffering capacity. Bioresour. Technol. 2011, 102, 7077-7085. [CrossRef] [PubMed]

22. Reddy, M.V.; Chandrasekhar, K.; Mohan, S.V. Influence of carbohydrates and proteins concentration on fermentative hydrogen production using canteen based waste under acidophilic microenvironment. J. Biotechnol. 2011, 155, 387-395. [CrossRef] [PubMed]

23. Imbert, E. Food waste valorization options: Opportunities from the bioeconomy. Open Agric. 2017, 2, $195-204$. [CrossRef]

24. Venkata Mohan, S.; Nikhil, G.N.; Chiranjeevi, P.; Nagendranatha Reddy, C.; Rohit, M.V.; Kumar, A.N.; Sarkar, O. Waste biorefinery models towards sustainable circular bioeconomy: Critical review and future perspectives. Bioresour. Technol. 2016, 215, 2-12. [CrossRef] [PubMed]

25. Kannaiah Goud, R.; Venkata Mohan, S. Pre-fermentation of waste as a strategy to enhance the performance of single chambered microbial fuel cell (MFC). Int. J. Hydrogen Energy 2011, 36, 13753-13762. [CrossRef]

26. Scopus Document Search. Available online: www.scopus.com (accessed on 12 January 2018).

27. Villano, M.; Aulenta, F.; Majone, M. Perspectives of biofuels production from renewable resources with bioelectrochemical systems. Asia-Pac. J. Chem. Eng. 2012, 7, S263-S274. [CrossRef]

28. Chandrasekhar, K.; Venkata Mohan, S. Bio-electrochemical remediation of real field petroleum sludge as an electron donor with simultaneous power generation facilitates biotransformation of PAH: Effect of substrate concentration. Bioresour. Technol. 2012, 110, 517-525. [CrossRef] [PubMed]

29. Mohan, S.V.; Chandrasekhar, K. Self-induced bio-potential and graphite electron accepting conditions enhances petroleum sludge degradation in bio-electrochemical system with simultaneous power generation. Bioresour. Technol. 2011, 102, 9532-9541. [CrossRef] [PubMed]

30. Velvizhi, G.; Venkata Mohan, S. Multi-electrode bioelectrochemical system for the treatment of high total dissolved solids bearing chemical based wastewater. Bioresour. Technol. 2017, 242, 77-86. [CrossRef] [PubMed]

31. Moscoviz, R.; Toledo-Alarcón, J.; Trably, E.; Bernet, N. Electro-fermentation: How to drive fermentation using electrochemical systems. Trends Biotechnol. 2016, 34, 856-865. [CrossRef] [PubMed]

32. Schievano, A.; Pepé Sciarria, T.; Vanbroekhoven, K.; De Wever, H.; Puig, S.; Andersen, S.J.; Rabaey, K.; Pant, D. Electro-Fermentation-Merging Electrochemistry with Fermentation in Industrial Applications. Trends Biotechnol. 2016, 34, 866-878. [CrossRef] [PubMed]

33. Rabaey, K.; Clauwaert, P.; Aelterman, P.; Verstraete, W. Tubular microbial fuel cells for efficient electricity generation. Environ. Sci. Technol. 2005, 39, 8077-8082. [CrossRef] [PubMed]

34. He, Z.; Minteer, S.D.; Angenent, L.T. Electricity generation from artificial wastewater using an upflow microbial fuel cell. Environ. Sci. Technol. 2005, 39, 5262-5267. [CrossRef] [PubMed]

35. He, Z.; Wagner, N.; Minteer, S.D.; Angenent, L.T. An upflow microbial fuel cell with an interior cathode: Assessment of the internal resistance by impedance spectroscopy. Environ. Sci. Technol. 2006, 40, 5212-5217. [CrossRef] [PubMed] 
36. Zhang, B.; Zhang, J.; Yang, Q.; Feng, C.; Zhu, Y.; Ye, Z.; Ni, J. Investigation and optimization of the novel UASB-MFC integrated system for sulfate removal and bioelectricity generation using the response surface methodology (RSM). Bioresour. Technol. 2012, 124, 1-7. [CrossRef] [PubMed]

37. Feng, Y.; Lee, H.; Wang, X.; Liu, Y.; He, W. Continuous electricity generation by a graphite granule baffled air-cathode microbial fuel cell. Bioresour. Technol. 2010, 101, 632-638. [CrossRef] [PubMed]

38. Choi, O.; Sang, B.-I. Extracellular electron transfer from cathode to microbes: Application for biofuel production. Biotechnol. Biofuels 2016, 9, 11. [CrossRef] [PubMed]

39. Nikhil, G.N.; Suman, P.; Venkata Mohan, S.; Swamy, Y.V. Energy-positive nitrogen removal of pharmaceutical wastewater by coupling heterotrophic nitrification and electrotrophic denitrification. Chem. Eng. J. 2017, 326, 715-720. [CrossRef]

40. Wang, H.; Ren, Z.J. A comprehensive review of microbial electrochemical systems as a platform technology. Biotechnol. Adv. 2013, 31, 1796-1807. [CrossRef] [PubMed]

41. Zhang, Y.; Angelidaki, I. A new method for in situ nitrate removal from groundwater using submerged microbial desalination-denitrification cell (SMDDC). Water Res. 2013, 47, 1827-1836. [CrossRef] [PubMed]

42. Nikhil, G.N.; Yeruva, D.K.; Venkata Mohan, S.; Swamy, Y.V. Assessing potential cathodes for resource recovery through wastewater treatment and salinity removal using non-buffered microbial electrochemical systems. Bioresour. Technol. 2016, 215, 247-253. [CrossRef] [PubMed]

43. Chandrasekhar, K.; Ahn, Y.-H. Effectiveness of piggery waste treatment using microbial fuel cells coupled with elutriated-phased acid fermentation. Bioresour. Technol. 2017, 244 Pt 1, 650-657. [CrossRef] [PubMed]

44. Kiran Kumar, A.; Venkateswar Reddy, M.; Chandrasekhar, K.; Srikanth, S.; Venkata Mohan, S. Endocrine disruptive estrogens role in electron transfer: Bio-electrochemical remediation with microbial mediated electrogenesis. Bioresour. Technol. 2012, 104, 547-556. [CrossRef] [PubMed]

45. Liu, H.; Hu, H. Microbial Electrolysis: Novel Biotechnology for Hydrogen Production from Biomass. In Microbial Technologies in Advanced Biofuels Production; Hallenbeck, P.C., Ed.; Springer: Boston, MA, USA, 2012; pp. 93-105.

46. Zhu, X.; Hatzell, M.C.; Cusick, R.D.; Logan, B.E. Microbial reverse-electrodialysis chemical-production cell for acid and alkali production. Electrochem. Commun. 2013, 31, 52-55. [CrossRef]

47. Cheng, S.; Xing, D.; Call, D.F.; Logan, B.E. Direct biological conversion of electrical current into methane by electromethanogenesis. Environ. Sci. Technol. 2009, 43, 3953-3958. [CrossRef] [PubMed]

48. Rabaey, K.; Bützer, S.; Brown, S.; Keller, J.; Rozendal, R.A. High current generation coupled to caustic production using a lamellar bioelectrochemical system. Environ. Sci. Technol. 2010, 44, 4315-4321. [CrossRef] [PubMed]

49. Rozendal, R.A.; Leone, E.; Keller, J.; Rabaey, K. Efficient hydrogen peroxide generation from organic matter in a bioelectrochemical system. Electrochem. Commun. 2009, 11, 1752-1755. [CrossRef]

50. Cao, X.; Huang, X.; Liang, P.; Xiao, K.; Zhou, Y.; Zhang, X.; Logan, B.E. A new method for water desalination using microbial desalination cells. Environ. Sci. Technol. 2009, 43, 7148-7152. [CrossRef] [PubMed]

51. Zhang, B.; He, Z. Integrated salinity reduction and water recovery in an osmotic microbial desalination cell. RSC Adv. 2012, 2, 3265-3269. [CrossRef]

52. Forrestal, C.; Xu, P.; Jenkins, P.E.; Ren, Z. Microbial desalination cell with capacitive adsorption for ion migration control. Bioresour. Technol. 2012, 120, 332-336. [CrossRef] [PubMed]

53. Morel, A.; Zuo, K.; Xia, X.; Wei, J.; Luo, X.; Liang, P.; Huang, X. Microbial desalination cells packed with ion-exchange resin to enhance water desalination rate. Bioresour. Technol. 2012, 118, 43-48. [CrossRef] [PubMed]

54. Luo, H.; Jenkins, P.E.; Ren, Z. Concurrent desalination and hydrogen generation using microbial electrolysis and desalination cells. Environ. Sci. Technol. 2011, 45, 340-344. [CrossRef] [PubMed]

55. Chen, S.; Liu, G.; Zhang, R.; Qin, B.; Luo, Y. Development of the microbial electrolysis desalination and chemical-production cell for desalination as well as acid and alkali productions. Environ. Sci. Technol. 2012, 46, 2467-2472. [CrossRef] [PubMed]

56. Chen, X.; Xia, X.; Liang, P.; Cao, X.; Sun, H.; Huang, X. Stacked microbial desalination cells to enhance water desalination efficiency. Environ. Sci. Technol. 2011, 45, 2465-2470. [CrossRef] [PubMed]

57. Jacobson, K.S.; Drew, D.M.; He, Z. Use of a liter-scale microbial desalination cell as a platform to study bioelectrochemical desalination with salt solution or artificial seawater. Environ. Sci. Technol. 2011, 45, 4652-4657. [CrossRef] [PubMed] 
58. Aelterman, P.; Rabaey, K.; Pham, H.T.; Boon, N.; Verstraete, W. Continuous electricity generation at high voltages and currents using stacked microbial fuel cells. Environ. Sci. Technol. 2006, 40, 3388-3394. [CrossRef] [PubMed]

59. Cusick, R.D.; Kim, Y.; Logan, B.E. Energy capture from thermolytic solutions in microbial reverse-electrodialysis cells. Science 2012, 335, 1474-1477. [CrossRef] [PubMed]

60. Liu, H.; Grot, S.; Logan, B.E. Electrochemically assisted microbial production of hydrogen from acetate. Environ. Sci. Technol. 2005, 39, 4317-4320. [CrossRef] [PubMed]

61. Ditzig, J.; Liu, H.; Logan, B.E. Production of hydrogen from domestic wastewater using a bioelectrochemically assisted microbial reactor (BEAMR). Int. J. Hydrogen Energy 2007, 32, 2296-2304. [CrossRef]

62. Chae, K.-J.; Choi, M.-J.; Kim, K.-Y.; Ajayi, F.F.; Chang, I.-S.; Kim, I.S. A solar-powered microbial electrolysis cell with a platinum catalyst-free cathode to produce hydrogen. Environ. Sci. Technol. 2009, 43, 9525-9530. [CrossRef] [PubMed]

63. Kim, Y.; Logan, B.E. Hydrogen production from inexhaustible supplies of fresh and salt water using microbial reverse-electrodialysis electrolysis cells. Proc. Natl. Acad. Sci. USA 2011, 108, 16176-16181. [CrossRef] [PubMed]

64. Zhang, Y.; Angelidaki, I. Innovative self-powered submersible microbial electrolysis cell (SMEC) for biohydrogen production from anaerobic reactors. Water Res. 2012, 46, 2727-2736. [CrossRef] [PubMed]

65. Gong, Y.; Ebrahim, A.; Feist, A.M.; Embree, M.; Zhang, T.; Lovley, D.; Zengler, K. Sulfide-driven microbial electrosynthesis. Environ. Sci. Technol. 2013, 47, 568-573. [CrossRef] [PubMed]

66. Steinbusch, K.J.J.; Hamelers, H.V.M.; Schaap, J.D.; Kampman, C.; Buisman, C.J.N. Bioelectrochemical Ethanol Production through Mediated Acetate Reduction by Mixed Cultures. Environ. Sci. Technol. 2010, 44, 513-517. [CrossRef] [PubMed]

67. Nevin, K.P.; Hensley, S.A.; Franks, A.E.; Summers, Z.M.; Ou, J.; Woodard, T.L.; Snoeyenbos-West, O.L.; Lovley, D.R. Electrosynthesis of organic compounds from carbon dioxide is catalyzed by a diversity of acetogenic microorganisms. Appl. Environ. Microbiol. 2011, 77, 2882-2886. [CrossRef] [PubMed]

68. Rabaey, K.; Girguis, P.; Nielsen, L.K. Metabolic and practical considerations on microbial electrosynthesis. Curr. Opin. Biotechnol. 2011, 22, 371-377. [CrossRef] [PubMed]

69. Kim, Y.; Logan, B.E. Simultaneous removal of organic matter and salt ions from saline wastewater in bioelectrochemical systems. Desalination 2013, 308, 115-121. [CrossRef]

70. Hu, H.; Fan, Y.; Liu, H. Hydrogen production using single-chamber membrane-free microbial electrolysis cells. Water Res. 2008, 42, 4172-4178. [CrossRef] [PubMed]

71. Kumar, P.; Patel, S.K.S.; Lee, J.-K.; Kalia, V.C. Extending the limits of Bacillus for novel biotechnological applications. Biotechnol. Adv. 2013, 31, 1543-1561. [CrossRef] [PubMed]

72. Call, D.; Logan, B.E. Hydrogen production in a single chamber microbial electrolysis cell lacking a membrane. Environ. Sci. Technol. 2008, 42, 3401-3406. [CrossRef] [PubMed]

73. Modestra, J.A.; Babu, M.L.; Mohan, S.V. Electro-fermentation of real-field acidogenic spent wash effluents for additional biohydrogen production with simultaneous treatment in a microbial electrolysis cell. Sep. Purif. Technol. 2015, 150, 308-315. [CrossRef]

74. Chandrasekhar, K.; Pandit, S.; Kadier, A.; Dasagrandhi, C.; Velpuri, J. Biohydrogen production: Integrated approaches to improve the process efficiency. In Microbial Applications Vol. 1: Bioremediation and Bioenergy; Kalia, V.C., Kumar, P., Eds.; Springer International Publishing: Cham, Switzerland, 2017; pp. 189-210.

75. Villano, M.; Aulenta, F.; Ciucci, C.; Ferri, T.; Giuliano, A.; Majone, M. Bioelectrochemical reduction of $\mathrm{CO}_{2}$ to $\mathrm{CH}_{4}$ via direct and indirect extracellular electron transfer by a hydrogenophilic methanogenic culture. Bioresour. Technol. 2010, 101, 3085-3090. [CrossRef] [PubMed]

76. Jiang, Y.; Su, M.; Zhang, Y.; Zhan, G.; Tao, Y.; Li, D. Bioelectrochemical systems for simultaneously production of methane and acetate from carbon dioxide at relatively high rate. Int. J. Hydrogen Energy 2013, 38, 3497-3502. [CrossRef]

77. Marshall, C.W.; Ross, D.E.; Fichot, E.B.; Norman, R.S.; May, H.D. Long-term operation of microbial electrosynthesis systems improves acetate production by autotrophic microbiomes. Environ. Sci. Technol. 2013, 47, 6023-6029. [CrossRef] [PubMed]

78. Su, M.; Jiang, Y.; Li, D. Production of acetate from carbon dioxide in bioelectrochemical systems based on autotrophic mixed culture. J. Microbiol. Biotechnol. 2013, 23, 1140-1146. [CrossRef] [PubMed] 
79. Choi, O.; Kim, T.; Woo, H.M.; Um, Y. Electricity-driven metabolic shift through direct electron uptake by electroactive heterotroph Clostridium pasteurianum. Sci. Rep. 2014, 4, 6961. [CrossRef] [PubMed]

80. Zhou, M.; Chen, J.; Freguia, S.; Rabaey, K.; Keller, J. Carbon and electron fluxes during the electricity driven 1,3-Propanediol biosynthesis from glycerol. Environ. Sci. Technol. 2013, 47, 11199-11205. [CrossRef] [PubMed]

81. Xafenias, N.; Anunobi, M.O.; Mapelli, V. Electrochemical startup increases 1,3-propanediol titers in mixed-culture glycerol fermentations. Process Biochem. 2015, 50, 1499-1508. [CrossRef]

82. Bajracharya, S.; Ter Heijne, A.; Dominguez Benetton, X.; Vanbroekhoven, K.; Buisman, C.J.N.; Strik, D.P.B.; Pant, D. Carbon dioxide reduction by mixed and pure cultures in microbial electrosynthesis using an assembly of graphite felt and stainless steel as a cathode. Bioresour. Technol. 2015, 195, 14-24. [CrossRef] [PubMed]

83. Srikanth, S.; Venkateswar Reddy, M.; Venkata Mohan, S. Microaerophilic microenvironment at biocathode enhances electrogenesis with simultaneous synthesis of polyhydroxyalkanoates (PHA) in bioelectrochemical system (BES). Bioresour. Technol. 2012, 125, 291-299. [CrossRef] [PubMed]

84. Modestra, J.A.; Mohan, S.V. Microbial electrosynthesis of carboxylic acids through $\mathrm{CO}_{2}$ reduction with selectively enriched biocatalyst: Microbial dynamics. J. $\mathrm{CO}_{2}$ Util. 2017, 20, 190-199. [CrossRef]

85. Choi, K.-S.; Kondaveeti, S.; Min, B. Bioelectrochemical methane $\left(\mathrm{CH}_{4}\right)$ production in anaerobic digestion at different supplemental voltages. Bioresour. Technol. 2017, 245, 826-832. [CrossRef] [PubMed]

86. Clauwaert, P.; Tolêdo, R.; van der Ha, D.; Crab, R.; Verstraete, W.; Hu, H.; Udert, K.M.; Rabaey, K. Combining biocatalyzed electrolysis with anaerobic digestion. Water Sci. Technol. 2008, 57, 575-579. [CrossRef] [PubMed]

87. Wang, H.; Fotidis, I.A.; Angelidaki, I. Ammonia effect on hydrogenotrophic methanogens and syntrophic acetate-oxidizing bacteria. FEMS Microbiol. Ecol. 2015, 91, fiv130. [CrossRef] [PubMed]

88. Michalopoulos, I.; Chatzikonstantinou, D.; Mathioudakis, D.; Vaiopoulos, I.; Tremouli, A.; Georgiopoulou, M.; Papadopoulou, K.; Lyberatos, G. Valorization of the liquid fraction of a mixture of livestock waste and cheese whey for biogas production through high-rate anaerobic co-digestion and for electricity production in a microbial fuel cell (MFC). Waste Biomass Valoriz. 2017, 8, 1759-1769. [CrossRef]

89. Wang, A.; Liu, W.; Cheng, S.; Xing, D.; Zhou, J.; Logan, B.E. Source of methane and methods to control its formation in single chamber microbial electrolysis cells. Int. J. Hydrogen Energy 2009, 34, 3653-3658. [CrossRef]

90. Mézes, L.; Bai, A.; Nagy, D.; Cinka, I.; Gabnai, Z. Optimization of raw material composition in an agricultural biogas plant. Trends Renew. Energy 2017, 3, 61-75. [CrossRef]

91. Bai, A.; Grasselli, G.; Kormányos, S.; Szendrei, J. Economic evaluation of scaling of agricultural biogas plants. Hung. Agric. Eng. 2007, 20, 23-25.

92. Kumar, P.; Singh, M.; Mehariya, S.; Patel, S.K.S.; Lee, J.-K.; Kalia, V.C. Ecobiotechnological approach for exploiting the abilities of Bacillus to produce co-polymer of polyhydroxyalkanoate. Indian J. Microbiol. 2014, 54, 151-157. [CrossRef] [PubMed]

93. Pant, D.; Singh, A.; Van Bogaert, G.; Olsen, S.I.; Nigam, P.S.; Diels, L.; Vanbroekhoven, K. Bioelectrochemical systems (BES) for sustainable energy production and product recovery from organic wastes and industrial wastewaters. RSC Adv. 2012, 2, 1248-1263. [CrossRef]

94. Lee, B.; Park, J.-G.; Shin, W.-B.; Tian, D.-J.; Jun, H.-B. Microbial communities change in an anaerobic digestion after application of microbial electrolysis cells. Bioresour. Technol. 2017, 234, 273-280. [CrossRef] [PubMed]

95. Tartakovsky, B.; Manuel, M.F.; Neburchilov, V.; Wang, H.; Guiot, S.R. Biocatalyzed hydrogen production in a continuous flow microbial fuel cell with a gas phase cathode. J. Power Sources 2008, 182, 291-297. [CrossRef]

96. Clauwaert, P.; Verstraete, W. Methanogenesis in membraneless microbial electrolysis cells. Appl. Microbiol. Biotechnol. 2009, 82, 829-836. [CrossRef] [PubMed]

97. Sasaki, K.; Sasaki, D.; Morita, M.; Hirano, S.-I.; Matsumoto, N.; Ohmura, N.; Igarashi, Y. Bioelectrochemical system stabilizes methane fermentation from garbage slurry. Bioresour. Technol. 2010, 101, 3415-3422. [CrossRef] [PubMed]

98. Srikanth, S.; Kumar, M.; Singh, M.P.; Das, B.P. Bioelectro chemical systems: A sustainable and potential platform for treating waste. Procedia Environ. Sci. 2016, 35, 853-859. [CrossRef]

99. Kumar, P.; Mehariya, S.; Ray, S.; Mishra, A.; Kalia, V.C. Biodiesel industry waste: A potential source of bioenergy and biopolymers. Indian J. Microbiol. 2015, 55, 1-7. [CrossRef] 
100. Mathew, A.S.; Wang, J.; Luo, J.; Yau, S.-T. Enhanced ethanol production via electrostatically accelerated fermentation of glucose using Saccharomyces cerevisiae. Sci. Rep. 2015, 5, 15713. [CrossRef] [PubMed]

101. Shin, H.; Zeikus, J.; Jain, M. Electrically enhanced ethanol fermentation by Clostridium thermocellum and Saccharomyces cerevisiae. Appl. Microbiol. Biotechnol. 2002, 58, 476-481. [CrossRef] [PubMed]

102. Song, Y.; Wang, J.; Yau, S.-T. Controlled glucose consumption in yeast using a transistor-like device. Sci. Rep. 2014, 4, 5429. [CrossRef] [PubMed]

103. Jeon, B.Y.; Hwang, T.S.; Park, D.H. Electrochemical and biochemical analysis of ethanol fermentation of Zymomonas mobilis KCCM11336. J. Microbiol. Biotechnol. 2009, 19, 666-674. [PubMed]

104. Torella, J.P.; Gagliardi, C.J.; Chen, J.S.; Bediako, D.K.; Colón, B.; Way, J.C.; Silver, P.A.; Nocera, D.G. Efficient solar-to-fuels production from a hybrid microbial-water-splitting catalyst system. Proc. Natl. Acad. Sci. USA 2015, 112, 2337-2342. [CrossRef] [PubMed]

105. Thygesen, A.; Thomsen, A.B.; Possemiers, S.; Verstraete, W. Integration of microbial electrolysis cells (MECs) in the biorefinery for production of ethanol, $\mathrm{H}_{2}$ and phenolics. Waste Biomass Valoriz. 2010, 1, 9-20. [CrossRef]

106. Kumar, P.; Ray, S.; Patel, S.K.S.; Lee, J.-K.; Kalia, V.C. Bioconversion of crude glycerol to polyhydroxyalkanoate by Bacillus thuringiensis under non-limiting nitrogen conditions. Int. J. Biol. Macromol. 2015, 78, 9-16. [CrossRef] [PubMed]

107. Singh, M.; Kumar, P.; Ray, S.; Kalia, V.C. Challenges and opportunities for customizing polyhydroxyalkanoates. Indian J. Microbiol. 2015, 55, 235-249. [CrossRef] [PubMed]

108. Kumar, P.; Jun, H.-B.; Kim, B.S. Co-production of polyhydroxyalkanoates and carotenoids through bioconversion of glycerol by Paracoccus sp. strain LL1. Int. J. Biol. Macromol. 2018, 107, 2552-2558. [CrossRef] [PubMed]

109. Kumar, P.; Ray, S.; Kalia, V.C. Production of co-polymers of polyhydroxyalkanoates by regulating the hydrolysis of biowastes. Bioresour. Technol. 2016, 200, 413-419. [CrossRef] [PubMed]

110. Pantazaki, A.A.; Papaneophytou, C.P.; Lambropoulou, D.A. Simultaneous polyhydroxyalkanoates and rhamnolipids production by Thermus thermophilus HB8. AMB Express 2011, 1, 17. [CrossRef] [PubMed]

111. Redwood, M.D.; Orozco, R.L.; Majewski, A.J.; Macaskie, L.E. Electro-extractive fermentation for efficient biohydrogen production. Bioresour. Technol. 2012, 107, 166-174. [CrossRef] [PubMed]

112. Redwood, M.D.; Orozco, R.L.; Majewski, A.J.; Macaskie, L.E. An integrated biohydrogen refinery: Synergy of photofermentation, extractive fermentation and hydrothermal hydrolysis of food wastes. Bioresour. Technol. 2012, 119, 384-392. [CrossRef] [PubMed] 